\title{
Uma análise do desenvolvimento conceitual da sociologia de Pierre Bourdieu a partir da obra "os herdeiros"
}

\author{
An analysis of the conceptual development of Pierre Bourdieu's sociology from \\ the work "the inheritors"
}

Lucas Voigt ${ }^{1}$

\begin{abstract}
Resumo
Este artigo realiza uma análise do desenvolvimento conceitual da sociologia de Pierre Bourdieu a partir de um dos primeiros trabalhos publicados pelo autor, "Os herdeiros: os estudantes e a cultura" (1964). Inicialmente, o artigo irá apresentar uma visão geral da obra Os herdeiros. Em seguida, são apresentados alguns dos principais conceitos da sociologia de Pierre Bourdieu, articulando as formulações incipientes contidas na obra com os desenvolvimentos da sociologia madura do autor. Argumenta-se que é possível constatar em Os herdeiros um esboço incipiente de noções importantes para a sociologia bourdieusiana, tais como habitus, capital cultural, campo, herança, violência simbólica, illusio e racismo de classe. Do mesmo modo, a obra comporta reflexões que posteriormente serão abandonadas por Bourdieu, como sua proposta de uma "pedagogia racional", bem como sua utilização da noção de "ideologia". Assim, Os herdeiros - estudo inaugural de Pierre Bourdieu e JeanClaude Passeron no campo da sociologia da educação - mostra-se uma obra exemplar e profícua para a análise do desenvolvimento conceitual e do percurso intelectual da sociologia de Pierre Bourdieu.
\end{abstract}

Palavras-chave: Pierre Bourdieu, Os herdeiros, sociologia da educação, desenvolvimento conceitual.

\begin{abstract}
This article analyzes the conceptual development of Pierre Bourdieu's sociology from one of the first works published by the author, "The Inheritors: French Students and Their Relations to Culture" (1964). First, the article will present an overview of the book The Inheritors. Next, some of the main concepts of Pierre Bourdieu's sociology are presented, articulating the incipient formulations contained in the book with the developments of the author's mature sociology. It is argued that it is possible to verify in the work an incipient outline of important notions for Bourdieus's sociology, such as habitus, cultural capital, field, inheritance, symbolic violence, illusio and class racism. In the same way, the work contains reflections that later will be abandoned by Bourdieu, like its proposal of a "rational pedagogy", as well as its use of the notion of "ideology". Thus, The Inheritors - an inaugural study of Pierre Bourdieu and Jean-Claude Passeron in the field of sociology of education - is an exemplary and fruitful work for the analysis of the conceptual development and intellectual course of Pierre Bourdieu's sociology.
\end{abstract}

Keywords: Pierre Bourdieu, The Inheritors, sociology of education, conceptual development.

\footnotetext{
1 Sociólogo e Mestre em Sociologia Politica (UFSC), Doutorando em Sociologia (UFRGS). Email: lucas_3106@hotmail.com. Cidade: Porto Alegre
} 


\section{Introdução}

Este artigo tem por objetivo realizar uma análise do desenvolvimento conceitual da sociologia de Pierre Bourdieu (1930-2002) a partir da obra "Os herdeiros: os estudantes e a cultura" ("Les héritiers: les étudiants et la culture"), escrita em parceira com o também sociólogo Jean-Claude Passeron (1930-) (BOURDIEU; PASSERON, 2014).

A obra, publicada originalmente em 1964, teve tradução recente e tardia para a língua portuguesa, em 2014, pela Editora da Universidade Federal de Santa Catarina (UFSC). A tradução do livro é assinada por Ione Ribeiro Valle - professora do Centro de Ciências da Educação da referida Universidade e especialista na sociologia bourdieusiana - e Nilton Valle. A tradução se insere em um contexto de esforços recentes da Editora da UFSC para a publicação de obras inéditas de Pierre Bourdieu no Brasil, especialmente os trabalhos que integram a sua "sociologia da educação". A obra Homo Academicus já fora traduzida, alguns anos antes, por esta editora (BOURDIEU, 2013).

O contexto social e histórico de produção da obra Os herdeiros é marcado pela explosão demográfica na Europa após a Segunda Guerra Mundial e, de modo correlato, pelo consequente aumento da demanda pelo acesso ao sistema de ensino superior. Como constatam Bourdieu e Passeron (2014), o número de indivíduos das classes menos privilegiadas que chegavam à universidade à época era extremamente reduzido. De modo geral, a trajetória escolar destes agentes era marcada pelo "fracasso escolar", que minava e clivava as chances de acesso à educação superior. A universidade francesa caracterizava-se, assim, como um espaço restrito basicamente às elites.

Os herdeiros constitui-se como um ensaio de pequeno porte, fortemente embasado em material empírico. A obra se baseia em dados estatísticos produzidos por instituições oficiais de estatística da França, bem como estudos empíricos realizados pelos autores com estudantes e professores universitários franceses. O livro é considerado um marco no campo da sociologia da educação, inaugurando uma agenda de pesquisas na área, que atribui importância à dimensão empírica nos estudos sobre o 
Uma análise do desenvolvimento conceitual da sociologia de Pierre Bourdieu a partir da obra "os herdeiros" | Lucas Voigt

sistema de ensino, não se limitando a divagações de cunho meramente pedagógico ou normativo.

Em linhas gerais, o objetivo primordial de Os herdeiros é atestar a relação entre o destino escolar e a origem social dos estudantes. A obra representa uma das primeiras reflexões dos autores sobre as interfaces entre educação e desigualdade social, que marcarão seus trabalhos mais importantes, especialmente a aclamada A reprodução (BOURDIEU; PASSERON, 2011). Pode-se argumentar que $A$ reprodução - obra de cunho mais teórico e enfocada no ensino básico - é uma consequência da pesquisa iniciada em Os herdeiros - de cunho empírico, analisando o ensino superior. Além disso, ambas as obras nos permitem qualificar a sociologia da educação de Bourdieu e de Passeron como uma sociologia das desigualdades ${ }^{2}$.

Conforme argumenta Valle (2014), no prefácio de Os herdeiros, o objetivo central da obra é explicitar as regras do jogo universitário e demonstrar o papel dos sistemas de ensino na reprodução das desigualdades sociais. Na perspectiva de Bourdieu e Passeron, a escola atua na reprodução das estruturas sociais ao legitimar e valorizar um corpo de saberes que é próprio das elites, sob o manto da "meritocracia" e do "dom pessoal".

Deve-se salientar - como já foi sinalizado inúmeras vezes - que a sociologia de Bourdieu, especialmente sua sociologia da educação, tem relações estreitas com a sua própria trajetória e experiência pessoais. Bourdieu, proveniente de uma família de origem camponesa, nasceu na pequena comuna de Denguin (na província de Béarn), no departamento dos Pirineus Atlânticos, situada no sudoeste da França (NOGUEIRA; NOGUEIRA,

\footnotetext{
2 Após terem trabalhado conjuntamente em importantes obras até o início da década de 1970, como as já citadas, e também em A profissão de sociólogo (BOURDIEU; CHAMBOREDON; PASSERON, 1999), Bourdieu e Passeron acabaram mantendo um distanciando intelectual nas décadas seguintes. $\mathrm{Na}$ obra $\mathrm{O}$ culto e o popular, escrita em parceria com Claude Grignon, Passeron formula uma critica direta às ideias de Bourdieu (GRIGNON; PASSERON, 1991). Os autores identificam duas abordagens sobre a cultura popular, a relativista e a legitimista (ou miserabilista). Na perspectiva legitimista - que associam a Bourdieu -, caberia à cultura dominante definir as representações culturais válidas. Como argumentam Nogueira e Nogueira (2004), para Bourdieu a cultura popular não seria um sistema simbólico autônomo e capaz de se opor à cultura dominante. Tal perspectiva, segundo Grignon e Passeron (1991), se focaria no grupo dominante, colocando a cultura popular em uma posição dependente em relação à cultura erudita. Assim, este "dominocentrismo" acaba definindo a cultura popular por aquilo que lhe falta, não por aquilo que lhe é próprio.
} 
2004). Em sua região, próxima à Espanha, falava-se um dialeto gascão. Assim, Bourdieu nasceu em uma região distante dos polos de produção da cultura francesa, em uma classe desprivilegiada e onde se praticava um dialeto distinto da língua considerada socialmente legítima ${ }^{3}$. Portanto, ao se tornar o principal representante da sociologia francesa de sua época, Bourdieu pode ser considerado como uma exceção às suas próprias teorias sobre a reprodução social e as chances de acesso ao ensino superior em função da origem social.

Os herdeiros nos permite avaliar o desenvolvimento conceitual da sociologia de Pierre Bourdieu. Na obra, podemos constatar um esboço incipiente de noções importantes para a sociologia do autor, tais como habitus, capital, campo, herança, violência simbólica, illusio e racismo de classe. Do mesmo modo, vemos reflexões que posteriormente serão abandonadas por Bourdieu, como sua proposta de uma "pedagogia racional", bem como sua utilização da noção de "ideologia". Desta forma, Os herdeiros - um dos primeiros trabalhos de Bourdieu e seu estudo inaugural no campo da sociologia da educação - mostra-se uma obra exemplar e proficua para a análise do desenvolvimento da sociologia do autor. Este é o caminho que me proponho a seguir neste artigo.

\section{Uma visão geral da obra "os herdeiros"}

$\mathrm{Na}$ obra Os herdeiros, Bourdieu e Passeron (2014) realizam um movimento analítico que, partindo de uma exposição e descrição sobre a desigualdade no ensino superior e sua relação com a origem social dos estudantes (primeiro capítulo), passando por uma análise sobre a condição estudantil, a relação dos estudantes com a cultura, com o meio intelectual e com o sistema de ensino (segundo e terceiro capítulos), culmina em uma prescrição pedagógica que tem por objetivo reduzir os efeitos da origem social no sistema universitário (conclusão). Nesta seção, irei expor as principais ideias desenvolvidas pelos autores, seguindo a própria estrutura da obra. Na seção seguinte, algumas dessas ideias serão retomadas em

\footnotetext{
${ }^{3}$ Em determinados trechos do interessante documentário A sociologia é um esporte de combate (Pierre Carles, 2001), é possivel encontrar alguns apontamentos sobre a origem social e familiar de Bourdieu, na visão do próprio autor.
} 
Uma análise do desenvolvimento conceitual da sociologia de Pierre Bourdieu a partir da obra "os herdeiros" | Lucas Voigt

maior profundidade, enquanto outras formulações presentes na obra serão introduzidas, com a finalidade de analisar o desenvolvimento conceitual da sociologia de Pierre Bourdieu a partir das reflexões esboçadas em Os herdeiros.

No primeiro capitulo, "A escolha dos eleitos", Bourdieu e Passeron discutem um conjunto de estatísticas que explicitam a desigualdade no ensino superior na França. A obra constata que as diversas camadas sociais compõem desigualmente o sistema universitário. Ao apresentarem estatísticas sobre a desigualdade no que tange às chances objetivas de acesso à universidade, os autores demonstram que quanto mais desfavorecida a classe social, menores as chances de ingresso no ensino superior. Assim, postulam uma relação entre a origem social dos sujeitos e o processo de seleção dos "eleitos" para as universidades.

Um dos argumentos centrais de Bourdieu e Passeron é que a origem social é o principal fator de diferenciação no meio estudantil, mais importante do que variáveis como o sexo, a idade ou a afiliação religiosa dos estudantes. Nas palavras dos autores: "Definindo chances, condições de vida ou de trabalho totalmente diferentes, a origem social é, de todos os determinantes, o único que estende sua influência a todos os domínios e a todos os niveis da experiência dos estudantes e primeiramente às condições de existência". (BOURDIEU; PASSERON, 2014, p. 28).

Os autores elegem as faculdades de letras como o terreno ideal para o estudo dos fatores culturais da desigualdade diante da escola. Segundo Bourdieu e Passeron, no ensino literário ${ }^{4}$ - um meio intelectual, culto e erudito - a influência da origem social se manifesta mais claramente, demonstrando de forma exemplar o modo de relação com a cultura que os autores pretendem analisar. As faculdades de letras seriam uma escolha forçada para as classes mais baixas, e um refúgio para as classes mais favorecidas, que buscam direcionar seus estudos a uma "razão social".

Um dos elementos relacionados à desigualdade social no sistema de ensino refere-se à condição estudantil. Como mostram Bourdieu e Passeron,

\footnotetext{
4 É válido lembrar que, no sistema universitário francês, as faculdades de letras envolvem as ciências humanas - como a sociologia - e as humanidades em geral.
} 
os estudantes - em seu papel de estudantes - têm em comum o fato de estudar; mas mesmo tendo determinadas práticas compartilhadas, não possuem uma experiência idêntica ou coletiva. Em suma, não existe uma "condição estudantil" una. Para delinear a desigualdade da condição estudantil, os autores apontam fatores como o auxilio familiar e a moradia junto à família (maior entre os estudantes de classes altas), e a necessidade de trabalhar (maior entre os estudantes menos favorecidos). Neste sentido, a natureza e o montante de recursos familiares - e o grau de dependência em relação à família - separam os estudantes segundo sua origem social.

No entanto, os autores não se limitam a fatores meramente econômicos. Para Bourdieu e Passeron, as aptidões e as condutas no ensino carregam a marca das aquisições passadas. É neste sentido que os hábitos culturais herdados do meio familiar - conhecimento sobre literatura clássica, visita a museus, frequentação de teatros, etc. -contribuem para o sucesso escolar. Para os autores, a cultura escolar - que valoriza o domínio da "cultura livre" - é a cultura das classes altas; neste sentido, o privilégio cultural - que explicita os diferenciais de herança familiar segundo a origem social - contribui para o melhor desempenho dos estudantes oriundos das elites. Em outras palavras, a cultura escolar é uma cultura de classe, aprendida no meio familiar, própria às classes cultas. Como os autores argumentam: "Para os filhos de camponeses, de operários, de empregados ou de pequenos comerciantes, a aquisição da cultura escolar é aculturação". (BOURDIEU; PASSERON, 2014, p. 40, grifo meu).

Desta forma, Bourdieu e Passeron formulam sua critica à neutralidade do sistema escolar, demonstrando o caráter de classe das práticas educacionais e do trabalho de aprendizagem. O sucesso ou fracasso na escola, imputados ao "dom" natural ou à pessoa, são na verdade o efeito do meio familiar. É neste sentido que os autores se referem a uma "ideologia do dom", que transforma as aquisições oriundas da família e da posição na hierarquia social em "mérito" ou "dom" individual.

Esta herança cultural possibilita o diletantismo na condução dos estudos, característica dos estudantes de origem burguesa. Tais estudantes sentem menos a necessidade da tutela universitária, e desenvolvem uma 
Uma análise do desenvolvimento conceitual da sociologia de Pierre Bourdieu a partir da obra "os herdeiros" | Lucas Voigt

imagem romântica do trabalho intelectual. Para que tais mecanismos intelectuais se formem, são necessárias condições econômicas e sociais de possibilidade de escolhas. Por outro lado, os estudantes mais desfavorecidos, na falta de outros recursos, encontram na prática escolar um meio de compensar sua desvantagem. Nas palavras dos autores:

Para os indivíduos originários das camadas menos favorecidas, a
escola permanece a única via de acesso à cultura, e isso em todos os
níveis do ensino; portanto, ela seria a via real da democratização da
cultura se não consagrasse, ignorando-as, as desigualdades iniciais
em relação à cultura e se não chegasse com frequência - reprovando
por exemplo um trabalho escolar por ser muito "escolar" - a
desvalorizar a cultura que ela mesma transmite em favor da cultura
herdada que não leva a marca reles do esforço e tem, por isso, todas
as aparências da facilidade e da graça. (BOURDIEU; PASSERON,
2014, p. 38).

No segundo capitulo, "Jogos sérios e jogos de seriedade", Bourdieu e Passeron iniciam sua argumentação afirmando que a identidade da prática universitária não define um grupo integrado ou uma condição profissional. Neste sentido, os estudantes constroem sua autoimagem mais pela significação simbólica que conferem à sua prática, do que pela unidade ou identidade de suas condições de existência.

Neste contexto, os autores irão discutir o tempo e o espaço originais nos quais vivem os estudantes. Tais experiências, no entanto, não têm o poder de integrar os estudantes em um grupo coerente e coeso. Verifica-se também uma ausência de apoios institucionais para a integração dos estudantes. Segundo os autores, os estudantes, sobretudo os parisienses, nunca foram tão pouco integrados quanto no presente. Assim, nas palavras dos autores: "[...] tudo leva a duvidar que os estudantes constituam de fato um grupo social homogêneo, independente e integrado". (BOURDIEU; PASSERON, 2014, p. 55).

Os estudantes de letras, foco da análise de Bourdieu e Passeron, são aspirantes a intelectuais. O grupo constituído pelos estudantes é definido pela aspiração à cultura, o que favorece a adesão aos valores culturais e aos valores dos agentes que os transmitem - isto é, intelectuais e professores. Desta forma, os autores argumentam que os estudantes acabam por adquirir os valores da instituição universitária. Os estudantes passam a 
viver a vida e sua relação com a origem social segundo os modelos intelectuais.

Por consequência, os estudantes tendem a reproduzir a ortodoxia cultural. Segundo os autores, a universidade sempre prega aos convertidos, tendo como função última obter a adesão aos valores da cultura. Assim, o exercício simbólico da profissão de intelectual é uma das condições de adesão aos valores do mundo intelectual por parte dos estudantes. O tempo de estudos é visto como um ritual preparatório para uma vida intelectual. A aprendizagem não é, assim, vista como um meio, mas como um fim.

Bourdieu e Passeron, de forma sagaz, demonstram que pôr em questão a universidade e a cultura universitária é obedecer às regras do modelo universitário, de modo exemplar. A contestação faz parte das regras do jogo universitário, sendo considerada uma das características do exercício intelectual. Assim, a revolta contra o sistema escolar realiza os fins que persegue a universidade. Dito de outro modo, ser contestador não é ir contra a lógica universitária. Nas palavras dos autores: “[...] a revolta contra a imposição exterior da regra é uma das vias por onde se cumpre a interiorização dos valores que a regra impõe; como no mito freudiano, é com a morte do pai que começa o reino do pai introjetado" (BOURDIEU; PASSERON, 2014, p. 66).

Para os autores, o tipo ideal de estudante é aquele engajado à contracorrente, ao conformismo do anticonformismo. É neste sentido que Bourdieu e Passeron apontam as afinidades ideológicas dos estudantes especialmente os parisienses, visto que o tipo ideal delineado é o estudante parisiense filho de intelectuais, de origem burguesa e dotado de privilégios culturais - com a esquerda, o extremismo e a vanguarda. A busca por diferenciação por parte dos estudantes supõe um dissensus nos limites do consensus. Em outras palavras, o corpo de opiniões obrigatórias entre os estudantes permanece grosso modo idêntico, e as diferenças são meramente formais. Isso é possivel porque os valores do diletantismo que os estudantes burgueses associam ao meio estudantil estão em afinidade com os valores veiculados pelo ideal da intelectualidade. Estes estudantes, de origem burguesa, tendem a negar a influência do meio familiar na sua experiência e 
Uma análise do desenvolvimento conceitual da sociologia de Pierre Bourdieu a partir da obra "os herdeiros" | Lucas Voigt

demonstram um distanciamento em relação ao futuro profissional, encarando a experiência escolar como uma "aventura intelectual" 5.

Bourdieu e Passeron utilizam em vários momentos a ferramenta teórico-metodológica weberiana do tipo ideal (WEBER, 2003) para a análise das dimensões simbólicas e objetivas da condição de "estudante". O tipo ideal do estudante - parisiense, questionador, politizado e com pretensões intelectuais -, e a própria autoimagem que este estudante ideal constrói para definir a essência do "estudante", contrasta com as condições objetivas de existência no meio estudantil. Neste sentido, Bourdieu e Passeron irão apontar a irrealidade desta autoimagem da condição de estudante que, no entanto, exprime uma verdade objetiva do meio estudantil: trata-se de um grupo dominado por valores e hábitos burgueses.

Em síntese, para Bourdieu e Passeron o caráter questionador do meio estudantil é uma incorporação dos valores universitários e intelectuais; tais valores contribuem ainda para o ocultamento do papel da origem social e para a definição de uma prática estudantil marcada pela indiferença em relação aos estudos e às técnicas de trabalho intelectual, além da propensão a ideologias políticas extremistas. Tal atitude em relação à experiência estudantil é possibilitada por uma condição de privilégio.

Finalizando o segundo capítulo, os autores ressaltam que a condição estudantil não condena todas as categorias de estudantes a uma experiência irreal e lúdica da prática escolar. Alguns estudantes se colocam questões sobre seu propósito escolar com seriedade. Em outras palavras, a irrealidade da condição de estudante depende das condições de existência. Segundo os autores, em nome da "seriedade" dissimulam-se duas atitudes em relação à condição estudantil. Uma é a dos estudantes burgueses, que não colocam problemas mais sérios do que aqueles introduzidos pelo próprio meio acadêmico. Outra exprime a inquietude frente ao futuro dos estudantes vindos das camadas mais distantes da cultura escolar e condenados a vivê-

\footnotetext{
5 Bourdieu e Passeron formulam uma crítica às tendências estudantis de rebeldia e dissenso, marcadas pelo extremismo de esquerda e pela "irrealidade", e possibilitadas por uma condição existencial de caráter burguês, que atingiram seu ápice na França com o Maio de 68. Ao constatarem (ainda em 1964), por meio de uma crítica ácida, comportamentos e autoimagens do meio estudantil que se exacerbaram e se tornaram patentes com a explosão de rebeldia juvenil e utópica verificada em 1968, Bourdieu e Passeron demonstram uma grande capacidade analitica e a pertinência de suas formulações.
} 
la irrealmente. Assim, os "jogos de seriedade" estariam ligados a jogar o jogo universitário segundo suas regras, marcado por uma aventura intelectual e um dissenso nos marcos do consenso. Os "jogos sérios" representariam o questionamento da condição de estudante de uma forma realista, levando em conta o elemento da "origem social" e seus determinantes no sistema de ensino.

No terceiro capitulo, “Aprendizes ou aprendizes de feiticeiro?", Bourdieu e Passeron constroem para fins heurísticos um tipo ideal da conduta estudantil com base na racionalidade. Os autores reconhecem, no entanto, que há uma grande distância entre este modelo de conduta racional e a conduta real dos agentes. Segundo os autores, os estudantes e professores teriam a intenção de manter as vantagens que o sistema atual lhes oferece.

Segundo a concepção de Bourdieu e Passeron, a tarefa do estudante é trabalhar pelo seu próprio desaparecimento enquanto estudante. Ser estudante é, assim, preparar-se pelo estudo para um futuro profissional, e a ação de estudar é um meio para um fim que lhe é exterior. Os estudantes ocultam a verdade do seu trabalho, separando o presente do futuro profissional. É neste sentido que os autores formulam sua crítica à ilusão da aprendizagem como um fim em si mesmo. A aprendizagem tem como finalidade a ascensão a uma profissão, ainda que intelectual. A condição estudantil só pode manter sua seriedade se levar em conta o futuro profissional para o qual ela prepara.

Para Bourdieu e Passeron, o sistema de ensino francês se orienta segundo um modelo tradicional, e não racional: seu propósito é formar homens cultos, e não homens de profissão. Assim, o estudante de letras confunde o exercício escolar com uma aventura intelectual. Diferentemente de disciplinas em que o futuro profissional é mais palpável e exige uma formação para o exercício da profissão, os estudantes de disciplinas como a sociologia tendem a mistificar sua experiência escolar ${ }^{6}$.

\footnotetext{
6 Lévi-Strauss, cujo estruturalismo exerceu grande influência na sociologia de Bourdieu, em uma nota autobiográfica sobre as influências que o conduziram à etnologia (LÉVI-STRAUSS, 1957), argumenta que os estudantes de cursos como medicina e direito se preparam para o exercício profissional, libertando-se da escola e assumindo as exigências profissionais impostas pela sociedade. Por outro
} 
Uma análise do desenvolvimento conceitual da sociologia de Pierre Bourdieu a partir da obra "os herdeiros" | Lucas Voigt

No entanto, nem todos os estudantes mantêm esta mesma relação enganosa com sua experiência escolar. Os estudantes originários das classes baixas não podem tratar o ensino como uma aventura intelectual, pois os estudos são sua oportunidade de ascensão na hierarquia social. No polo oposto, os estudantes mais favorecidos não costumam organizar racionalmente sua prática em função de tarefas profissionais, atribuindo pouca importância à aquisição das técnicas que organizariam o trabalho intelectual. Nas palavras dos autores: "Estando rompida toda relação racional com o futuro provável, o presente se torna o lugar de onirismo que exclui a própria ideia de técnicas eficazes e da eficiência das técnicas". (BOURDIEU; PASSERON, 2014, p. 86).

É neste sentido que podemos entender a analogia dos autores, que define os estudantes como "aprendizes de feiticeiros". Na ausência de um modelo metódico de transmissão da cultura e das técnicas escolares na universidade, os meios de trabalho intelectual permanecem obscuros aos estudantes que não possuem uma herança cultural. Desta forma, a ascensão à "ordem dos feiticeiros" - isto é, ao meio acadêmico e intelectual seria um procedimento inatingível aos jovens não provenientes de famílias da elite. Com base em tais argumentos, Bourdieu e Passeron passam a esboçar sua proposta de uma pedagogia racional, isto é, um esforço visando racionalizar a arte de transmitir a adesão aos valores de cultura, que estaria alinhada aos interesses dos estudantes mais desfavorecidos.

$\mathrm{Na}$ "Conclusão" da obra, Bourdieu e Passeron retomam alguns de seus argumentos, e formulam de forma mais detalhada sua proposta de uma "pedagogia racional". Segundo os autores, quando se ignora as desigualdades sociais, as desigualdades de sucesso escolar são consideradas como desigualdades naturais e de dons. A universidade exige dos que entram no jogo - os estudantes e professores - que admitam as regras de uma competição baseada apenas em critérios escolares. Neste sentido, os

\footnotetext{
lado, em cursos como as letras e as ciências - em que as profissões se resumem ao professorado e à pesquisa - o estudante não abandona o universo infantil, mas conserva-o. Ser professor é a única forma de um adulto permanecer na escola, e a única forma de um estudante permanecer estudante. Lévi-Strauss fala ainda da antropologia como uma "profissão de refúgio". Nesta nota biográfica, podese perceber os valores intelectuais do diletantismo e o ideal da aprendizagem como um fim em si mesmo, que Bourdieu e Passeron (2014) criticam.
} 
agentes do meio universitário reproduzem a ideologia carismática do dom, que ignora as desigualdades sociais diante da escola e da cultura. O esforço de Bourdieu e Passeron objetivou questionar as desigualdades escolares, um questionamento sobre o próprio princípio sobre o qual repousa o sistema de ensino. Ao reconhecer o papel do privilégio cultural, enfraquece-se a ideologia que permite às classes privilegiadas atribuir ao seu sucesso escolar uma comprovação de dons naturais e pessoais.

Segundo Bourdieu e Passeron, um sistema educacional baseado na igualdade formal dos alunos não pode reconhecer outras desigualdades, do que aquelas provenientes de dons individuais. Como a função do sistema de educação é produzir sujeitos selecionáveis e hierarquizáveis, ele deve submeter os mesmos critérios a sujeitos fundamentalmente desiguais, isto é, o procedimento de seleção de alunos deve levar em conta apenas critérios escolares. Reside nisso a dificuldade para hierarquizar os estudantes segundo seu mérito real, isto é, segundo os obstáculos que superaram em função de sua origem social. No entanto, os autores argumentam que nada impede que se leve em conta as desigualdades sociais no ensino propriamente dito. Assim, Bourdieu e Passeron propõem uma pedagogia que vise neutralizar as desigualdades sociais, visto que o esforço igualitário permanecerá apenas formal enquanto as desigualdades não forem abolidas por meio da ação pedagógica.

Para os autores, não é suficiente constatar que a cultura escolar é uma cultura de classe, a cultura da classe culta. Eles criticam ainda a "ilusão populista" que pretende elevar à ordem da cultura ensinada pela escola as culturas próprias das classes mais desfavorecidas ${ }^{7}$. Certas aptidões exigidas pela escola definem a cultura erudita (por exemplo, o domínio da lingua culta). No entanto, o sistema de ensino só pode exigir tais aptidões se considerá-las susceptiveis de serem adquiridas por todos, por meio do exercício, e se fornecer os meios para tanto.

A proposta de Bourdieu e Passeron se insere assim nos marcos do ensino democrático, isto é, aquele que objetiva que o maior número de

\footnotetext{
7 A critica a este tipo de relativismo é corroborada por Grignon e Passeron (1991), que apontam que ao considerar a cultura popular como autônoma e ignorar os processos de legitimação de práticas culturais, os relativistas acabam recaindo em um "populismo".
} 
Uma análise do desenvolvimento conceitual da sociologia de Pierre Bourdieu a partir da obra "os herdeiros" | Lucas Voigt

indivíduos possivel aprenda o maior número de aptidões que caracterizam a cultura escolar. Ela se opõe ao ensino tradicional voltado à formação de elites, e ao ensino tecnocrático voltado à produção de especialistas. Segundo os autores, na ausência de uma pedagogia racional que neutralize a ação dos fatores sociais de desigualdade cultural, a vontade política de oferecer a todos chances iguais de ensino não consegue superar as desigualdades reais. Neste sentido, os autores defendem uma organização contínua de exercícios e tarefas e a racionalização dos meios de ensino, em uma ação verdadeiramente pedagógica, que revele a magia da prática intelectual. Desta forma, uma pedagogia racional, fundada na sociologia das desigualdades culturais, contribuiria para neutralizar os efeitos da origem social no sistema de ensino.

\section{O desenvolvimento conceitual da sociologia de Pierre Bourdieu a partir de "os herdeiros"}

A sociologia de Pierre Bourdieu, marcada pelo rigor conceitual e por um robusto embasamento empírico, adquiriu seu elevado grau de sofisticação teórico-metodológica no decorrer do desenvolvimento das pesquisas sociológicas executadas pelo autor. Isto nos auxilia a compreender a grande eficácia empírica e heurística da sociologia de Bourdieu, que se constitui mais como uma agenda de pesquisas do que como um modelo teórico acabado, e que centraliza a indissociabilidade entre teoria e empiria.

Nas próximas seções, proponho uma análise do desenvolvimento conceitual da sociologia de Pierre Bourdieu a partir da obra Os herdeiros. Para tanto, realizei uma classificação e um ordenamento de alguns dos conceitos-chave da sociologia do autor, visando organizar a exposição dos argumentos. Deve-se levar em conta que tal classificação é relativamente arbitrária, tendo finalidade estritamente analítica. $\mathrm{Na}$ sociologia bourdieusiana, os conceitos apresentam-se de modo interligado e interrelacionado, sendo mobilizados de forma articulada e conjunta no decorrer das pesquisas desenvolvidas pelo autor. 


\section{Classe, habitus, capital cultural}

Podemos iniciar nossa incursão à sociologia de Pierre Bourdieu apresentando as formulações do autor sobre classe e estratificação social. Na sociologia de Bourdieu, a abstração sobre estratificação social não envolve apenas elementos econômicos, como o volume de rendimentos de um indivíduo ou família, ou sua posição na estrutura produtiva. Ao analisar a desigualdade social e seus impactos no sistema escolar, Bourdieu e Passeron (2014) trazem à tona em Os herdeiros fatores como cultura, sexo e situação geográfica.

Apesar de podermos constatar uma influência de Karl Marx na sociologia de Bourdieu - assim como dos demais clássicos da sociologia, como Max Weber e Émile Durkheim -, o pensamento de Bourdieu em torno da questão da classe social está muito distante de uma dicotomia simplista entre proprietários dos meios de produção e não proprietários, em sentido estritamente econômico ${ }^{8}$. Bourdieu sempre defendeu uma apropriação dos clássicos da sociologia, e não sua exegese. É central na sociologia de Bourdieu a influência das condições objetivas na geração e na produção das práticas sociais. No entanto, tais condições objetivas não se restringem ao componente econômico - isto é, não há um monismo causal da economia em Bourdieu -, e não atuam de forma determinista na formação das práticas. Como veremos, a noção de habitus tem por objetivo lidar com o problema da formação das estruturais mentais e dos princípios de ação social, que estão na base das práticas sociais, representando um movimento de sofisticação teórica importante em relação à teoria sociológica clássica.

Em suas construções teóricas sobre a estrutura de desigualdade social, Bourdieu irá posicionar os agentes em função de uma variedade de capitais - social, linguístico, político, simbólico e, especialmente, o capital econômico e o capital cultural. Naquela que talvez seja a sua magnum opus, "A distinção: crítica social do julgamento" (BOURDIEU, 2007), publicada originalmente em 1979, Bourdieu analisa a construção do espaço social em

\footnotetext{
8 A concepção marxista de classe social encontra uma de suas formulações mais grosseiras no Manifesto do Partido Comunista (MARX; ENGELS, 1998). É verdade, no entanto, que em outras obras Marx complexifica sua análise de classes, como na brilhante As lutas de classes na França. (MARX, 2012).
} 
Uma análise do desenvolvimento conceitual da sociologia de Pierre Bourdieu a partir da obra "os herdeiros" | Lucas Voigt

função de dois princípios de diferenciação, o capital econômico e o capital cultural. Os agentes e os grupos sociais se posicionam em função do volume e da estrutura destes dois tipos de capital. O habitus, produto das posições sociais e, por consequência, do volume e da estrutura de capitais, opera as tomadas de posições dos indivíduos no espaço social, sendo responsável pela assunção de um estilo de vida caracterizado por determinados bens e práticas. A posição ocupada no espaço social é a posição ocupada na estrutura de distribuição de diferentes tipos de capital, e o volume de capitais comanda as tomadas de posição nas lutas para conservá-la ou transformá-la. Em função da correspondência entre as posições no espaço social e o habitus, as diferenças sociais se tornam diferenças simbólicas. (BOURDIEU, 1996b, 2007).

Bourdieu (1996b) propõe uma definição de classe social como o conjunto de agentes que ocupa uma posição social, definida pelo volume e pela estrutura dos capitais econômico e cultural. No entanto, deve-se ressaltar que a sociologia de Bourdieu utiliza a noção de classe como uma categoria sociológica. Bourdieu constrói classes que poderíamos definir, em certa medida, como "teóricas" - ainda que definidas segundo um forte embasamento empírico e estatístico -, mas não classes reais. Nas palavras do autor: "Isso não significa que elas [as pessoas próximas no espaço social] constituam uma classe, no sentido de Marx, isto é, um grupo mobilizado por objetivos comuns e particularmente contra uma outra classe" (BOURDIEU, 1996b, p. 25). Para Bourdieu, a classe teórica só se torna uma classe real por meio de um trabalho político de mobilização. É neste sentido que devemos compreender a afirmação provocadora de Bourdieu de que "as classes sociais não existem". Segundo o autor, "O que existe é um espaço social, um espaço de diferenças, no qual as classes existem de algum modo em estado virtual, pontilhadas, não como um dado, mas como algo que se trata de fazer". (BOURDIEU, 1996b, p. 27, grifo do autor). Por meio de sua concepção de classe social, Bourdieu também opera uma crítica ao conservadorismo - e, poderíamos incluir aqui autores orientados segundo uma perspectiva liberal e neoliberal -, que procuram negar a existência de 
classes. Segundo ele, negar as classes sociais é negar a existência de diferenças e princípios de diferenciação.

Podemos perceber de modo nítido uma crítica de Bourdieu tanto ao marxismo como ao liberalismo em Os herdeiros. Ao passo que Bourdieu e Passeron (2014) rejeitam um determinismo da esfera econômica e das condições objetivas de existência, os autores não poupam igualmente críticas às leituras liberais do sistema de ensino. A perspectiva liberal busca explicar o fracasso escolar com base em critérios meritocráticos, restritos aos individuos. Um dos esforços centrais em Os herdeiros é refutar a "ideologia do dom", que imputa o fracasso à ausência de qualidades pessoais, o que acabaria por naturalizar a desigualdade escolar e ignorar sua relação com a desigualdade social.

Como argumentei, para analisar a relação entre a posição social e a prática dos agentes, a noção de habitus adquire centralidade. Um dos primeiros trabalhos em que Bourdieu introduz o conceito de habitus é "Esboço de uma teoria da prática" (BOURDIEU, 1983), publicado originalmente em 1972. Nesta obra, Bourdieu propõe sua praxiologia, ou teoria da prática, que pretende romper com a dicotomia entre o objetivismo (estruturalismo) e o subjetivismo (fenomenologia, interacionismo simbólico) ${ }^{9}$. O autor procura superar tanto o estruturalismo que não dá nenhuma margem à agência, assim como as formulações fenomenológicas que analisam eventos isolados sem considerar os fatores sociologicamente relevantes, como a regularidade e a reprodução social. (BOURDIEU, 1983). Neste sentido, Bourdieu qualifica sua teoria como estruturalismo construtivista ou construcionismo estruturalista.

Não faz sentido à sociologia de Bourdieu uma separação entre as dimensões objetivas e subjetivas, visto que elas se constituem mutuamente nas práticas. Assim, é central em Bourdieu a existência de uma cumplicidade ontológica entre a "agência" e a "estrutura". No entanto, se formos manter tais dicotomias para fins argumentativos, poderíamos argumentar que a sintese entre o objetivismo e o subjetivismo na sociologia

\footnotetext{
9 À época da escrita de Os herdeiros, talvez o subjetivismo fosse mais bem representado pelo existencialismo de Jean-Paul Sartre, doutrina teórica amplamente difundida no contexto francês do período.
} 
Uma análise do desenvolvimento conceitual da sociologia de Pierre Bourdieu a partir da obra "os herdeiros" | Lucas Voigt

de Bourdieu se dá, acertadamente, pela via do objetivismo. Isto é, as estruturas e a posição social produzem e definem a ação dos indivíduos, que não pode ser compreendida fora dos quadros sociais que possibilitam sua existência:

\begin{abstract}
Para resumir essa relação complexa entre as estruturas objetivas e as construções subjetivas, situada além das alternativas comuns do objetivismo e do subjetivismo, do estruturalismo e do construtivismo e até do materialismo e do idealismo, costumo citar, deformando-a ligeiramente, uma fórmula célebre de Pascal: "O mundo me contém e me engole como um ponto, mas eu o contenho". O espaço social me engloba como um ponto. Mas esse ponto é um ponto de vista, princípio de uma visão assumida a partir de um ponto situado no espaço social, de uma perspectiva definida em sua forma e em seu conteúdo pela posição objetiva a partir da qual é assumida. O espaço social é a realidade primeira e última já que comanda até as representações que os agentes sociais podem ter dele. (BOURDIEU, 1996b, p. 27, grifos do autor).
\end{abstract}

Bourdieu compreende o habitus como um conjunto de disposições e de princípios classificatórios que geram práticas. O habitus são as estruturas estruturantes das práticas, que são ao mesmo tempo estruturadas pela posição social, pelo volume e pela estrutura de capitais disponíveis, e pelas práticas dos agentes. O habitus, enquanto princípio da ação prática - ou senso prático voltado à ação -, é marcado por um movimento contínuo de interiorização da exterioridade e de exteriorização da interioridade (BOURDIEU, 1983). Por meio do habitus, os indivíduos incorporam os elementos que definem sua posição social, gerando práticas que caracterizam um estilo de vida, característico de uma classe de agentes. Assim, "O habitus é esse princípio gerador e unificador que retraduz as características intrínsecas e relacionais de uma posição em um estilo de vida unívoco, isto é, em um conjunto unívoco de escolhas de pessoas, de bens, de práticas". (BOURDIEU, 1996b, p. 21-2) ${ }^{10}$.

O habitus se transforma com as práticas dos agentes, mas costuma ser um conjunto de princípios relativamente estável. Neste sentido, pode-se falar que perpassa à obra de Bourdieu uma sociologia da reprodução social. Uma das formulações mais acabadas da noção de habitus se encontra na

\footnotetext{
$10 \mathrm{O}$ conceito de habitus foi apropriado e ressignificado por Bourdieu, dentre outras referências, a partir dos trabalhos de Erwin Panofsky sobre a relação entre o pensamento escolástico e a arquitetura gótica (BOURDIEU, 2010).
} 
principal obra de caráter teórico de Bourdieu, “O senso prático", originalmente publicada em 1980, logo após A distinção:

Os condicionamentos associados a uma classe particular de condições de existência produzem habitus, sistemas de disposições duráveis e transponiveis, estruturas estruturadas predispostas a funcionar como estruturas estruturantes, ou seja, como princípios geradores e organizadores de práticas e de representações que podem ser objetivamente adaptadas ao seu objetivo sem supor a intenção consciente de fins e o domínio expresso das operações necessárias para alcançá-los, objetivamente "reguladas" e "regulares" sem em nada ser o produto da obediência a algumas regras e, sendo tudo isso, coletivamente orquestradas sem ser o produto da ação organizadora de um maestro. (BOURDIEU, 2009, p. 87, grifo do autor).

Relacionado às concepções sobre classe, estratificação social e habitus, temos um terceiro conceito central à sociologia de Bourdieu: a noção de capital, isto é, os recursos disponiveis e que podem ser mobilizados por um agente em sua trajetória. Como já argumentei, o volume de capital envolverá variados recursos - econômicos, simbólicos, culturais, etc. À nossa discussão, será especialmente importante a noção de capital cultural (BOURDIEU, 1998) - isto é, os recursos culturais relacionados ao acesso à educação e ao sistema de ensino, à frequentação de museus, cinema, teatro, etc. -, que já está implícita em Os herdeiros, e é essencial para que se compreendam as desigualdades do sistema escolar.

Deve-se salientar que em nenhum momento da obra Os herdeiros Bourdieu e Passeron (2014) utilizam as noções de habitus ou capital cultural. Na verdade, quando os autores referem-se a "classes privilegiadas", que possuem maior sucesso escolar, não parece haver uma distinção clara entre as noções de "classe privilegiada" e "classe culta", isto é, não há uma reflexão satisfatória sobre a estrutura do capital desta classe, nem uma diferenciação precisa entre o capital econômico e o capital cultural. Não obstante, vejamos como a obra já traz implícitas noções como habitus e capital cultural em sua estrutura argumentativa. Tal exercício nos permitirá verificar a influência das constatações empíricas das pesquisas de Bourdieu para o desenvolvimento teórico de sua sociologia, que alcançou sua fase madura nas obras supracitadas. 
Uma análise do desenvolvimento conceitual da sociologia de Pierre Bourdieu a partir da obra "os herdeiros" | Lucas Voigt

Em Os herdeiros, Bourdieu e Passeron (2014) afirmam que as classes mais baixas têm chances simbólicas de enviar seus filhos à universidade. As chances objetivas de acesso ao ensino superior, no entanto, se expressam de muitas maneiras no campo da subjetividade. Neste sentido, os estudos superiores são considerados um futuro "impossível" pelas classes mais desfavorecidas. Em outras palavras, a esperança subjetiva é até mesmo mais baixa do que as chances objetivas de acesso à universidade. Os autores argumentam que determinações sociais não precisam ser conscientemente percebidas para forçarem os sujeitos a se determinarem em relação a elas, isto é, em relação ao futuro objetivo de sua categoria social. Os sujeitos das classes menos privilegiadas não conhecem as estatísticas de chances de acesso ao ensino superior, mas as introjetam e incorporam. É neste sentido que podemos afirmar que os sujeitos pensam segundo as suas possibilidades objetivas, o que implica uma homologia funcional entre as estruturas mentais e as estruturas sociais. Tal reflexão traz implícita a própria noção de habitus, isto é, a interiorização da exterioridade - a incorporação das estruturas sociais e o reconhecimento da posição social - e a exteriorização da interioridade - a definição do ensino superior como um futuro impossivel.

Bourdieu e Passeron (2014) destacam a taxa de sucesso escolar diferencial segundo as classes sociais. Para os autores, há uma ação direta dos hábitos culturais e das disposições herdadas do meio de origem no sucesso escolar. O sucesso escolar depende, por exemplo, da aptidão para manejar a língua. Esta habilidade de manejo da língua - ou capital linguístico, nos termos da sociologia madura de Bourdieu - é própria das classes cultas. Para sustentar este argumento, os autores apontam a relação entre a origem social e o estudo de obras literárias clássicas, além do fato das classes privilegiadas costumarem estudar latim e grego. Além disso, Bourdieu e Passeron (2014) apontam que as classes mais favorecidas possuem um privilégio cultural decorrente da frequentação de teatros, museus, concertos e demais espaços de cultura. Assim, os estudantes mais favorecidos não devem ao seu meio de origem apenas hábitos e atitudes 
aplicáveis às tarefas escolares, mas herdam também saberes e um "bom gosto" - um capital cultural - com rentabilidade escolar indireta.

Conforme argumentam Bourdieu e Passeron (2014), quanto mais elevada a origem social, mais ricos os conhecimentos em qualquer dominio cultural. Não obstante, as desigualdades em relação à cultura são maiores em dominios onde inexiste um ensino organizado. Todavia, mesmo que determinado domínio cultural seja objeto de ensino formal - como as obras do teatro clássico, no exemplo dos autores -, o conhecimento sobre tal manifestação artística não implica as mesmas atitudes ou valores em relação à cultura. Segundo Bourdieu e Passeron (2014), é a maneira pessoal de realizar os atos culturais que lhes conferem a qualidade propriamente "cultural". Em outras palavras, as classes mais baixas podem demonstrar um mesmo conhecimento escolar sobre um fenômeno artístico, sem possuir a mesma cultura. Assim, há uma diferença entre a aprendizagem cultural por meio da escola, e uma aprendizagem que é consequência da educação familiar. Para os autores, uma cultura puramente escolar não é apenas uma cultura parcial, mas uma cultura inferior, pois os elementos que a compõem não têm o sentido que teriam num contexto mais amplo.

Para as classes favorecidas, a educação escolar é uma continuação da educação do meio familiar. Nas famílias da elite, verifica-se uma transmissão de herança cultural de maneira "natural" e "discreta", sem um esforço metódico característico do ensino formal. Nas palavras de Bourdieu e Passeron (2014, p. 42): "Para uns, a aprendizagem da cultura da elite é uma conquista, pela qual se paga caro; para outros, uma herança que compreende ao mesmo tempo a facilidade e as tentações de facilidade". Portanto, os estudantes são apenas formalmente iguais na aquisição de cultura, pois divergem no conjunto de predisposições e de pré-saberes - isto é, divergem no habitus - decorrente de seu meio de origem; em outras palavras, os estudantes divergem pelo sistema de traços culturais que partilham com sua classe de origem.

Desta forma, todo ensino pressupõe um corpo de saberes que é patrimônio das classes cultas. Esses saberes são "naturais" a uma classe, porque são a cultura dessa classe. Em virtude disso, Bourdieu e Passeron 
Uma análise do desenvolvimento conceitual da sociologia de Pierre Bourdieu a partir da obra "os herdeiros" | Lucas Voigt

(2014) argumentam que a educação não é universal, apesar de suas pretensões à universalidade e à igualdade formal dos estudantes, que acabam por ignorar a desigualdade de privilégios e de herança. Mesmo na hipótese de inexistir uma desigualdade econômica acentuada, a educação ainda seria de elite; isto é, os obstáculos econômicos não são suficientes para explicar a variação das taxas de sucesso escolar segundo as classes sociais, pois existem obstáculos culturais e diferenças de atitudes e aptidões definidas em relação à posição social que a família e a classe de origem do estudante ocupam.

Para sintetizar a discussão exposta até o momento, podemos reformular os argumentos desenvolvidos por Bourdieu e Passeron (2014) em Os herdeiros, mobilizando os conceitos-chave da sociologia madura de Bourdieu: (1) os estudantes oriundos das classes cultas são dotados de um maior volume de capital cultural e linguístico, inscrito nos seus grupos de pertencimento, como a família e a classe; (2) estes estudantes introjetam disposições e valores comuns aos demais membros que ocupam a mesma posição social; (3) tais disposições, este habitus de classe, geram práticas e comportamentos adequados à cultura escolar - responsáveis por seu "sucesso escolar" - e alinhados aos valores que permeiam o ambiente intelectual e a alta cultura; (4) o habitus das classes cultas opera nos sujeitos que as integram uma associação entre, de um lado, as condições de existência e as chances objetivas de acesso ao ensino superior, e de outro, a experiência subjetiva da prática estudantil e a relação que tais sujeitos mantêm com a cultura e com as tarefas escolares, vivenciadas com "tentações de facilidade", autonomia e como uma "aventura intelectual"; (5) as afinidades entre a cultura escolar e a cultura das classes cultas atestam o caráter de classe da educação, espaço definido por valores e práticas de elite; (6) o reconhecimento da não neutralidade e universalidade do sistema educacional permite uma explicação mais adequada do "fracasso escolar", visto que os sujeitos oriundos das classes menos privilegiadas não possuem inscritas em seu habitus as disposições necessárias à cultura escolar, privilégio das classes cultas; (7) assim, compreende-se o papel da escola 
para a reprodução social, pois o sistema de educação acaba por consagrar as desigualdades sociais sob a aparência de ignorá-las.

\section{Campo}

Outro conceito-chave da sociologia bourdieusiana que já se encontra em estado incipiente em Os herdeiros, ainda que de modo mais latente, é a noção de campo. Para Bourdieu, pode-se dizer, “[...] deformando a expressão de Hegel, [que] o real é relacional”. (BOURDIEU, 2010, p. 28, grifo do autor). Assim, o campo é entendido como um espaço social de relações objetivas, de hierarquias e distinções, e de luta entre agentes que concorrem pelo estabelecimento de definições e práticas legítimas. O campo enquanto um espaço social é um espaço de diferenças entre agentes. Por meio das diferenças - em termos de capital - e das relações entre as diferenças, é que os agentes ocupam ou procuram alterar suas posições no campo.

A noção de campo se baseia numa releitura estruturalista de um capítulo da célebre obra Economia e Sociedade, de Max Weber, em que Bourdieu propõe a noção de campo religioso enquanto "estrutura de relações objetivas", visando explicar as interações concretas que Weber descrevia na forma de uma tipologia (BOURDIEU, 2010). Em sua sociologia da religião, Weber aponta um processo de complexificação, especialização e diferenciação social em curso na modernidade, explicitado por uma autonomização das "esferas de valor", que passam a constituir uma "legalidade própria", isto é, critérios e principios autônomos para a definição dos elementos de legitimidade próprios a cada esfera (WEBER, 1982) ${ }^{11}$. Baseado nas formulações de Weber, Bourdieu definirá o campo como um espaço relativamente autônomo, com sua lógica interna própria, irredutivel à lógica que rege outros campos.

Em Os herdeiros, Bourdieu e Passeron (2014) afirmam que o meio estudantil não é autônomo, isto é, que a definição da condição e da autoimagem do estudante depende de critérios produzidos em outros

\footnotetext{
11 Não cabe aqui discutir em detalhes a interessante e complexa formulação de Weber (1982). Não obstante, é pertinente indicar que este processo de autonomização das esferas é resultado das rejeições religiosas do mundo: as religiões de salvação estavam em tensão com o mundo, e passaram a negá-lo; isto foi responsável pela eticização das condutas - isto é, a racionalização do mundo - e pela limitação da influência da religião nas demais esferas da vida.
} 
Uma análise do desenvolvimento conceitual da sociologia de Pierre Bourdieu a partir da obra "os herdeiros" | Lucas Voigt

campos, como o acadêmico e o artístico. O grupo dos estudantes não é coeso nem coerente, não partilha os mesmos valores, e a experiência estudantil comum não é suficiente para unificá-los. Além disso, não existe uma identidade das condições de existência dos estudantes, o que torna difícil a integração deste grupo social.

Em sua análise, Bourdieu e Passeron (2014) inserem os agentes em múltiplos campos, levando em conta, por exemplo, a atuação política dos estudantes, sua relação com a cultura, a influência do meio familiar e dos recursos econômicos na condição estudantil, a relação dos estudantes com a religião, e assim por diante. Portanto, pode-se argumentar que o meio estudantil se define de forma heterônoma em relação a uma série de campos - tais como o acadêmico, o artístico, o político, o econômico, o religioso - que imputam critérios de legitimidade incorporados nas práticas e nas construções simbólicas dos estudantes, definindo o "meio estudantil".

\section{Herança, racismo de classe, violência simbólica}

A noção de herança adquiriu importância nos trabalhos de Pierre Bourdieu, especialmente em sua sociologia da arte. Em As regras da arte (BOURDIEU, 1996a), publicada originalmente em 1992, através da análise da obra A educação sentimental de Gustave Flaubert, Bourdieu argumenta de modo sugestivo que a herança também herda o herdeiro, isto é, a herança implica a disposição de um agente para ocupar certa posição social, e reproduzir um habitus específico. O herdeiro não é apenas um recipiente de uma variedade de capitais e de bens materiais e simbólicos, mas, ao herdálos, acaba por assumir um conjunto de disposições e um estilo de vida condizente com a herança recebida.

A ideia de que existe uma cumplicidade entre a herança social e a assunção de um habitus condizente com os bens materiais e simbólicos herdados, pode ser verificada de modo incipiente em Os herdeiros. Bourdieu e Passeron (2014, p. 43) argumentam que: "A ameaça da dilapidação está vinculada ao próprio fato de herdar, sobretudo quando se trata de cultura, isto é, de uma aquisição na qual a maneira de adquirir é constitutiva daquilo que é adquirido". Em outras palavras, para que um estudante herde um 
determinado volume de capital cultural, é necessário que ele incorpore as disposições e habilidades necessárias ao manejo de bens culturais e da cultura. A herança, assim, não se resume à mera aquisição de bens objetivos - sejam materiais ou simbólicos -, mas envolve a formação das práticas e das competências culturais dos agentes. Para retomarmos novamente a noção de habitus, a herança depende da interiorização dos elementos estruturantes e comuns ao conjunto de agentes que ocupa uma mesma posição social, e compartilha determinada herança cultural.

Em toda a obra, Bourdieu e Passeron (2014) atribuem um grande peso à hereditariedade cultural, bem como às diferentes formas de apropriação e de representação simbólica desta herança. Segundo os autores: "As classes privilegiadas encontram na ideologia que se poderia chamar de carismática (pois valoriza a 'graça' ou o 'dom') uma legitimação de seus privilégios culturais que são assim transformados de herança social em graça individual ou em mérito pessoal". (BOURDIEU; PASSERON, 2014, p. 94-95). Ao transformarem uma herança social em mérito individual, as classes cultas - e o próprio sistema escolar - dissimulam um "racismo de classe", que atribui às classes privilegiadas qualidades que seriam intrinsecamente superiores - um suposto talento "inato" -, ignorando o papel dos privilégios culturais na formação das disposições e das condutas adequadas ao âmbito da cultura escolar.

Em seus trabalhos posteriores, vemos que Bourdieu desenvolverá a noção de racismo de classe, mencionada apenas en passant em Os herdeiros. Conforme argumenta Valle (2013a, 2013b), o termo racismo de classe foi utilizado nas análises de Pierre Bourdieu sobre La noblesse d'État ${ }^{12}$. Segundo a autora, de forma semelhante ao que ocorre com a nobreza militar, a nobreza escolar escolhe individuos de "essência superior", que por suas supostas capacidades intelectuais mais elevadas, seriam merecedores das posições sociais que ocupam.

Nas palavras de Bourdieu: "devemos ter presente que não há um racismo, mas racismos: há tantos racismos como grupos que têm

\footnotetext{
12 A importante obra "La noblesse d'État: Grandes écoles et esprit de corps", ainda não possui tradução em lingua portuguesa.
} 
Uma análise do desenvolvimento conceitual da sociologia de Pierre Bourdieu a partir da obra "os herdeiros" | Lucas Voigt

necessidade de se justificar por existirem como existem, o que constitui a função invariante dos racismos" (BOURDIEU, 2003, p. 277, grifo do autor). A noção de racismo de classe pode ser compreendida como um conjunto de representações e autorrepresentações das elites que associam aos estratos mais baixos da estrutura social um estatuto de inferioridade intelectual, que seria da sua própria natureza. O "racismo da inteligência", que atribui às classes menos privilegiadas uma inteligência inferior, é uma das manifestações mais típicas do racismo de classe. O racismo de classe oculta que o maior volume de capital cultural das classes cultas seja na verdade um privilégio - afinal, os bens materiais e simbólicos são desigualmente distribuídos -, dissimulando o papel da herança diferencial de capitais segundo as distintas posições sociais ocupadas pelas famílias e pelas classes no espaço social. Para Bourdieu, o melhor desempenho de indivíduos destas classes no sistema escolar, ao invés de ser o reflexo das suas capacidades superiores, decorre da herança cultural que partilham e, consequentemente, de um habitus adequado e mais "eficiente" no contexto das instituições escolares. Em outras palavras, o sucesso escolar das classes privilegiadas não se explica em função de propriedades intrínsecas que caracterizariam uma inteligência superior, mas em virtude da sua melhor adequação aos critérios e exigências que definem a "inteligência" no sistema de ensino.

Para que o racismo de classe obtenha sua eficácia social, ele depende da execução de uma violência simbólica. Como argumentam Bourdieu e Passeron (2014), as classes mais desfavorecidas acabam por incorporar a ideologia carismática do dom. Nas palavras dos autores: "Essa alquimia se realiza ainda melhor quando, longe de lhe opor uma outra imagem do sucesso escolar, as classes populares retomam por sua conta o essencialismo das classes altas e vivem sua desvantagem como destino pessoal" (BOURDIEU; PASSERON, 2014, p. 95). Os estudantes das classes menos privilegiadas tendem a avaliar seus resultados com base na ideologia dom; o baixo rendimento é atribuído à própria natureza do estudante, enquanto o fracasso escolar é imputado à falta de dons.

Segundo Bourdieu e Passeron (2014), quanto mais desfavorecida uma classe social, maior a introjeção da ideologia do dom. Na base desta 
formulação, está implicada a noção de violência simbólica, isto é, aquela que depende da aquiescência do dominado. O conceito de violência simbólica, importante em vários trabalhos de Bourdieu, implica que o poder simbólico "só se exerce se for reconhecido, quer dizer, ignorado como arbitrário" (BOURDIEU, 2010, p. 14, grifo do autor). O poder simbólico de criar representações sociais se define em uma relação entre os que exercem o poder e aqueles sobre os quais ele é exercido; para que seja eficaz, é necessária a crença em sua legitimidade. Quando os dominados reconhecem a legitimidade do poder, verifica-se então o que Bourdieu chama de violência simbólica. Ainda que a noção de violência simbólica não seja mencionada por Bourdieu e Passeron (2014), Os herdeiros fornece um substrato empírico abundante à noção, sendo que ela está implicada de modo embrionário em vários trechos da obra. Para citarmos uma vez mais os autores: “[...] a autoridade legitimadora da escola pode redobrar as desigualdades sociais porque as classes mais desfavorecidas, muito conscientes de seu destino e muito inconscientes das vias pelas quais ele se realiza, contribuem para a sua realização" (BOURDIEU; PASSERON, 2014, p. 97).

\section{Illusio, Homo Academicus}

Em As regras da arte, Bourdieu define a illusio como uma ilusão de realidade compartilhada em determinado espaço social. Os campos sociais são um espaço de lutas, comparável a um jogo. Partilhar uma illusio implica um investimento no jogo. Este investimento depende do reconhecimento dos jogos sociais como jogos sérios. A crença nas regras do jogo que regem determinado campo é a base para os investimentos realizados pelos agentes, visando à lucratividade segundo os critérios definidos e válidos no campo. É nesse sentido que, em função da illusio, a lógica de um campo pode ser regida por um "interesse desinteressado", isto é, a lucratividade no campo não se define necessariamente por critérios econômicos; no caso do campo artístico analisado por Bourdieu, a illusio reconhece apenas a lucratividade simbólica, caracterizando-se por uma rejeição de quaisquer interesses materiais (BOURDIEU, 1996a). 
Uma análise do desenvolvimento conceitual da sociologia de Pierre Bourdieu a partir da obra "os herdeiros" | Lucas Voigt

Tais formulações já se encontram relativamente bem desenvolvidas em Os herdeiros. No caso do meio estudantil, do sistema universitário e do campo acadêmico francês, podemos afirmar que os agentes partilham uma illusio orientada segundos valores intelectuais e da cultura, investindo no jogo em busca de sucesso no campo. Nas palavras dos autores:

\begin{abstract}
Se o universo escolar evoca por mais de uma forma o universo do jogo, campo de aplicação de regras que somente valem quando se aceita jogar, espaço e tempo limitados, delimitados, arrancados do mundo real no qual pesam os determinismos, é porque, mais do que outro jogo, ele propõe ou impõe aos jogadores a tentação de prenderse no jogo levando a crer que coloca todo seu ser em jogo. (BOURDIEU; PASSERON, 2014, p. 65).
\end{abstract}

Bourdieu e Passeron (2014) apontam que o sistema universitário está mais próximo do jogo do que do trabalho, considerando as sanções que envolvem os exames escolares. Para os autores, as provas e as sanções escolares são marcadas por uma irrealidade, socialmente aceita e compartilhada. O estudante busca no valor que o julgamento da escola outorga aos seus trabalhos o sinal de sua eleição ao meio intelectual. Em outras palavras, seu interesse é ser reconhecido pelo sistema escolar e pelo meio intelectual. Quando aceita jogar, o agente não questiona as regras do jogo; sua preocupação é alterar sua posição no campo.

O meio estudantil partilha uma illusio, determinada de forma heterônoma em relação a outros campos. Conforme fora discutido previamente, como os estudantes são aspirantes à cultura, eles vivem segundo modelos intelectuais, encarando os estudos como uma "aventura intelectual". Tais valores são produzidos em relação ao meio acadêmico e intelectual. Segundo Bourdieu e Passeron (2014), o meio estudantil é dominado por valores burgueses, o que implica que seus jogos se orientem segundo um "espírito de seriedade". Como os estudantes das camadas menos privilegiadas sentem em maior grau a irrealidade da prática estudantil, eles tendem a questionar a função e a realidade objetiva da prática escolar e estudantil, isto é, a formação para uma profissão.

Conforme argumentam Bourdieu e Passeron (2014), tanto estudantes como professores são produtos do sistema de ensino. Os estudantes aplicam à sua prática estudantil critérios do meio intelectual. Desta forma, rejeitam a 
aprendizagem intelectual por meio do treinamento e do exercício. Verifica-se, assim, um desprezo pelos meios racionais de controle necessários ao exercício de uma profissão. Os estudantes procuram aderir aos truques intelectuais, mais mágicos do que técnicos: "De sua parte, porque lhes agrada mais e custa-lhes menos acreditar no carisma do que controlar laboriosamente técnicas, os estudantes condenam-se a uma imagem do sucesso escolar na qual, na ausência do dom, somente a magia pode agir". (BOURDIEU; PASSERON, 2014, p. 86). De modo semelhante, há uma rejeição do corpo professoral à pedagogia e a aulas sobre as técnicas materiais de trabalho intelectual. Desse modo, o ensino superior carece de uma transmissão adequada das técnicas e hábitos de pensamento exigidos à prática universitária. Como argumentam Bourdieu e Passeron (2014), as técnicas profissionais fazem parte da magia da prática acadêmica, e seu ocultamento é central ao carisma professoral.

Por esse caminho, pode-se aferir que algumas das regras que regem o jogo universitário e acadêmico - no contexto analisado por Bourdieu e Passeron (2014) - são a adesão aos valores da intelectualidade e da cultura, a indiferença em relação às técnicas materiais e intelectuais de trabalho, além da prática do dissenso nos limites do consenso, conforme discutido anteriormente.

A partir da discussão exposta, podemos compreender algumas das características atribuídas por Bourdieu ao homo academicus. Segundo o autor: "O homo academicus gosta do acabado" (BOURDIEU, 2010, p. 19), isto é, o acadêmico não revela os critérios de julgamento e os procedimentos técnicos que caracterizam a prática intelectual, criando a imagem de que seu trabalho é o resultado de uma execução mágica possivel apenas àqueles que possuem o carisma intelectual ${ }^{13}$. Em Homo Academicus (BOURDIEU, 2013), obra publicada originalmente em 1984, Bourdieu irá analisar em detalhes a estrutura do campo acadêmico francês, a lógica que rege a prática dos intelectuais e os mecanismos de consagração de agentes de destaques no

\footnotetext{
13 Em Os herdeiros, ao discutir a questão dos estudantes premiados por concursos, Bourdieu e Passeron (2014) delineiam um tipo ideal do homo academicus em sua forma juvenil: oriundo de família de professores, que visa se dedicar à pesquisa e ao ensino, e que valoriza as obras clássicas.
} 
Uma análise do desenvolvimento conceitual da sociologia de Pierre Bourdieu a partir da obra "os herdeiros" | Lucas Voigt

campo, além da violência simbólica operada pelo sistema universitário formulações apresentadas de modo bastante preliminar em Os herdeiros.

\section{Pedagogia racional, ideologia}

Por fim, mostra-se pertinente apresentarmos algumas das ideias, presentes em Os herdeiros, que foram abandonadas nos trabalhos posteriores de Pierre Bourdieu. Refiro-me, basicamente, a duas formulações: a proposta de uma pedagogia racional e a utilização da noção de ideologia.

Conforme argumentam Bourdieu e Passeron (2014), uma democratização real do ensino pressupõe que as técnicas do trabalho intelectual sejam ensinadas na escola. É neste sentido que os autores propõem sua pedagogia racional fundada na sociologia das desigualdades culturais. Segundo os autores, as habilidades necessárias ao trabalho intelectual podem ser adquiridas de duas formas: como uma herança social, ou como uma aquisição laboriosa. Considerando que a maioria dos estudantes, em função da sua origem social, não possui as habilidades necessárias à prática acadêmica, Bourdieu e Passeron (2014) propõe transmitir estes "dons" por meio de um ensino metódico. Nas palavras dos autores:

[...] cada progresso no sentido da racionalidade real, quer se trate da explicitação das exigências recíprocas dos professores e dos estudantes ou ainda da melhor organização dos estudos para permitir aos estudantes das classes desfavorecidas superar suas desvantagens, seria um progresso no sentido da equidade: os estudantes originários das classes baixas, que são os primeiros a sofrer com todos os vestígios carismáticos e tradicionais e que estão mais que os outros inclinados a tudo esperar e a tudo exigir do ensino, seriam os primeiros a se beneficiar de um esforço para levar a todos esse conjunto de "dons" sociais que constituem a realidade do privilégio cultural. (BOURDIEU; PASSERON, 2014, p. 100-1).

Para Bourdieu e Passeron (2014), a prática acadêmica deve ser desmistificada, deixando de ser tratada como uma "aventura intelectual" ou um trabalho aristocrático, cuja finalidade é a formação de homens cultos. Uma pedagogia racional deveria se voltar à formação para uma profissão, isto é, propiciar aos estudantes uma preparação diversificada às tarefas profissionais que terão que executar. Para que isso seja alcançado, é necessária a transmissão das técnicas do trabalho intelectual, por meio de 
uma educação pautada pelo exercício e pela tarefa. Em uma pedagogia racional, os professores devem "revelar o segredo" da prática intelectual - as técnicas materiais de trabalho, os critérios de julgamento -, visto que seu ocultamento serve apenas à glória do carisma professoral e à exclusão das classes desfavorecidas.

Deve-se ter em mente que tal proposta de uma pedagogia racional esboçada em Os herdeiros, não será retomada nas obras posteriores de Bourdieu, tendo permanecido em estado incipiente. Conforme argumentam Nogueira e Nogueira (2002):

Nos seus primeiros trabalhos, o próprio Bourdieu falava da possibilidade de uma "pedagogia racional", que ao invés de supor como dados os pré-requisitos necessários à decodificação da comunicação pedagógica (capital cultural e linguístico), se esforçaria para transmiti-los metodicamente a quem não os recebeu na família. Esse otimismo pedagógico, no entanto, foi rapidamente abandonado. Prevalece na obra de Bourdieu a percepção de que o processo de reprodução das estruturas sociais por meio da escola é, basicamente, inevitável. (NOGUEIRA; NOGUEIRA, 2002, p. 34).

Não obstante, a ideia do trabalho intelectual como uma profissão, assim como o reconhecimento da importância da transmissão das técnicas materiais e intelectuais do trabalho acadêmico, permaneceram como princípios importantes na sociologia de Bourdieu. Em um seminário ministrado em 1987, Bourdieu afirmou que gostaria de poder inculcar a ideia da: "[...] pesquisa como uma atividade racional - e não como uma espécie de busca mística, de que se fala com ênfase para se sentir confiante" (BOURDIEU, 2010, p. 18). A proximidade de tal formulação com as ideias propostas em Os herdeiros é notável. Desse modo, embora Bourdieu não tenha avançado na prescrição de uma pedagogia racional para o sistema de ensino francês, nos seus cursos sobre metodologia e pesquisa sociológica, o autor procurou colocar em prática suas concepções pedagógicas.

Bourdieu dedicou conferências e publicações à transmissão da "magia" e do "ritual" da prática do sociólogo (ver, por exemplo: BOURDIEU, 2010, especialmente o segundo capítulo; BOURDIEU, CHAMBOREDON, PASSERON, 1999; BOURDIEU, 2004). Subjaz aos trabalhos de Bourdieu uma concepção da sociologia e do trabalho intelectual como um métier - isto é, um "ofício", uma profissão. É neste sentido que Bourdieu elenca algumas 
Uma análise do desenvolvimento conceitual da sociologia de Pierre Bourdieu a partir da obra "os herdeiros" | Lucas Voigt

premissas epistemológicas e metodológicas aplicáveis ao ofício do sociólogo, como a construção dos quadros de caracteres pertinentes a um conjunto de agentes ou instituições, o pensamento relacional, o modus operandi do trabalho sociológico, e assim por diante (BOURDIEU, 2010).

No que tange à noção de ideologia, largamente mobilizada em Os herdeiros - Bourdieu e Passeron (2014) chegam a se referir a uma "sociologia das ideologias" -, pode-se argumentar que, embora o conceito se apresente de modo ocasional em alguns trabalhos posteriores de Bourdieu, não se trata de uma noção central à sociologia do autor. Em um debate com Terry Eagleton (BOURDIEU; EAGLETON, 1992), Bourdieu afirma que procurou evitar o uso do termo ideologia, conceito frequentemente utilizado de forma vaga e equivocada, e encarado atualmente com descrédito nas ciências sociais. Bourdieu procurou substituir tal noção pelos conceitos de poder simbólico, violência simbólica e doxa - este último se refere à visão dominante em determinado campo social.

Para Bourdieu, a noção de ideologia operaria uma separação entre a falsa consciência e a consciência verdadeira. Na tradição marxista, supõe-se que o acadêmico teria a habilidade de alcançar a verdadeira consciência, capacidade que estaria ausente aos demais agentes sociais. Para Bourdieu, no entanto: "The social world doesn't work in terms of consciousness; it works in terms of practices, mechanisms and so forth." (BOURDIEU; EAGLETON, 1992, p. 113, grifo meu). Os sistemas educacionais, por exemplo, produzem uma distribuição desigual de capitais, mobilizando mecanismos de legitimação para tal processo. Tais mecanismos são inconscientes, do âmbito da prática dos agentes, sendo incorporados e aceitos como legítimos. Este processo de violência simbólica - o reconhecimento da legitimidade de determinado poder, isto é, o não questionamento da sua arbitrariedade - não pode ser descrito apropriadamente por meio da noção de ideologia. O conceito de ideologia, ao invés de reconhecer os processos de incorporação dos discursos e mecanismos que legitimam determinada prática social, restringir-se-ia à constatação simplista de que os agentes sociais estariam sendo guiados por uma falsa consciência. 


\section{Considerações finais}

Para qualquer leitor minimamente familiarizado com a sociologia de Pierre Bourdieu, mostra-se surpreendente constatar o autor propondo uma discussão de cunho normativo e prescritivo, como ocorre com a sua proposta de uma pedagogia racional. Como qualquer autor, durante sua trajetória intelectual Bourdieu modificou suas concepções, em função do desenvolvimento das suas pesquisas e das contingências da sua própria trajetória e biografia social. Assim, se em Os herdeiros Bourdieu e Passeron (2014) procuraram apresentar alternativas ao fenômeno da reprodução social realizada pela escola, em A reprodução (BOURDIEU; PASSERON, 2011) - obra muito mais sofisticada em termos teóricos - os autores abandonam suas pretensões propositivas sobre o sistema de ensino.

Desta forma, podemos reconhecer na sociologia de Bourdieu uma teoria desmobilizadora quanto às possibilidades de transformação social através da escola. Nas palavras do próprio Bourdieu, marcadas por um tom de ironia: "Este é o problema com os sociólogos. Por isso eu sempre pareço triste, pessimista e determinista. Eu nunca digo 'deveria"'14. Cabe à sociologia, enquanto ciência, a descrição e a explicação "objetiva" - no sentido weberiano - do mundo social, tal como ele se apresenta. À pedagogia - ainda que embasada pela sociologia, da qual tem muito a ganhar - cabe a definição dos critérios que devem orientar a educação. Nessa perspectiva, introduzir em uma análise sociológica elementos normativos ou aspirações politicas ou "ideológicas" acaba por comprometer o rigor da análise. Os trabalhos de Bourdieu - marcados por um rigor conceitual e um sólido embasamento empírico - são importantes para o desvelamento do papel do sistema de ensino para a perpetuação da desigualdade social, e tal esforço por si só já exerce um impacto político e uma função simbólica. No entanto, tais análises rigorosas nos remetem igualmente à eficácia do poder simbólico exercido pelo sistema educacional, além de demonstrarem como a lógica do sistema escolar tem reproduzido a estrutura de desigualdade vigente no espaço social. A sociologia da educação de Pierre Bourdieu demonstra, em

14 Trecho de uma entrevista concedida por Bourdieu no documentário A sociologia é um esporte de combate. 
Uma análise do desenvolvimento conceitual da sociologia de Pierre Bourdieu a partir da obra "os herdeiros" | Lucas Voigt

última instância, os limites e as dificuldades de transformação do sistema escolar. Para mencionarmos Bourdieu uma última vez: "I am seen as pessimistic, as discouraging the people and so on. But I think it is better to know the truth" (BOURDIEU; EAGLETON, 1992, p. 114).

Por fim, visando apresentar um fechamento ao artigo, retomando os principais argumentos desenvolvidos ao longo da discussão, apresento a seguir um quadro que sintetiza o modo como os principais conceitos formulados por Pierre Bourdieu e Jean-Claude Passeron são apresentados em Os herdeiros, contrastando-os com as formulações conceituais da sociologia "madura” de Pierre Bourdieu.

\begin{tabular}{|c|c|c|}
\hline Conceito & Em Os herdeiros & Na sociologia "madura" de Pierre Bourdieu \\
\hline $\begin{array}{l}\text { Classe } \\
\text { social }\end{array}$ & $\begin{array}{l}\text { Conceito é largamente utilizado na } \\
\text { obra. A diferenciação em termos de } \\
\text { classe de origem e a desigualdade } \\
\text { cultural entre as classes são centrais } \\
\text { à análise. Não há, entretanto, uma } \\
\text { distinção satisfatória entre "classes } \\
\text { privilegiadas" e "classes cultas". }\end{array}$ & $\begin{array}{c}\text { A noção de classe, enquanto conjunto de agentes } \\
\text { que ocupa uma mesma posição no espaço social, } \\
\text { em função do volume e da estrutura de capitais a } \\
\text { que têm acesso, mostrar-se-á uma das ideias } \\
\text { centrais da sociologia de Bourdieu. Ela alcança } \\
\text { seu grau mais sofisticado de elaboração em } A \\
\text { distinção (1979). }\end{array}$ \\
\hline Habitus & $\begin{array}{l}\text { Conceito não é utilizado na obra, } \\
\text { embora esteja implícito, } \\
\text { especialmente na formulação sobre a } \\
\text { homologia entre possibilidades } \\
\text { objetivas e subjetivas de acesso ao } \\
\text { ensino superior e no papel das } \\
\text { disposições incorporadas para o } \\
\text { sucesso escolar. }\end{array}$ & $\begin{array}{l}\text { Conceito se consolidará como um dos mais } \\
\text { importantes da sociologia de Bourdieu. Será } \\
\text { refinado em Esboço de uma teoria da prática } \\
\text { (1972), obtendo seu grau mais sofisticado de } \\
\text { formulação em O senso prático (1980). O conceito } \\
\text { representa a sintese bourdieusiana entre } \\
\text { subjetivismo e objetivismo; refere-se ao principio } \\
\text { gerador das práticas sociais. }\end{array}$ \\
\hline $\begin{array}{l}\text { Capital } \\
\text { cultural }\end{array}$ & $\begin{array}{l}\text { Conceito não é utilizado na obra, } \\
\text { embora esteja largamente implícito. } \\
\text { Não há, entretanto, uma reflexão } \\
\text { satisfatória sobre a estrutura do } \\
\text { capital das "classes privilegiadas". }\end{array}$ & $\begin{array}{l}\text { Conceito se consolidará como um dos mais } \\
\text { importantes da sociologia bourdieusiana. Ao lado } \\
\text { do capital econômico, é o principal principio de } \\
\text { definição das posições e da estrutura social de } \\
\text { desigualdade. Em sua sociologia madura, } \\
\text { Bourdieu identificará três tipos de capital cultural: } \\
\text { incorporado, objetivado e institucionalizado. }\end{array}$ \\
\hline Campo & $\begin{array}{l}\text { Conceito não é utilizado na obra e } \\
\text { apresenta-se de modo extremamente } \\
\text { incipiente. O “meio estudantil" é } \\
\text { definido de forma heterônoma em } \\
\text { relação a outros "campos". }\end{array}$ & $\begin{array}{l}\text { Conceito será formulado após a releitura } \\
\text { estruturalista da sociologia da religião de Max } \\
\text { Weber, e refinado após a análise de variados } \\
\text { campos por Bourdieu, com destaque às } \\
\text { formulações sobre o campo científico (em que se } \\
\text { encontra a versão mais bem acabada e sintética da } \\
\text { compreensão de Bourdieu sobre o conceito). }\end{array}$ \\
\hline Herança & $\begin{array}{l}\text { A ideia de herança está } \\
\text { compreendida em toda a obra } \\
\text { (inclusive no título), de modo } \\
\text { relativamente bem desenvolvido. }\end{array}$ & $\begin{array}{c}\text { A noção de herança, como ato recíproco de herdar } \\
\text { e ser herdado, obterá projeção e destaque na } \\
\text { sociologia de Bourdieu em As regras da arte } \\
\text { (1992). }\end{array}$ \\
\hline $\begin{array}{l}\text { Racismo de } \\
\text { classe }\end{array}$ & $\begin{array}{l}\text { Conceito está presente na obra, em } \\
\text { alto grau de elaboração. }\end{array}$ & $\begin{array}{c}\text { Conceito será retomado em La noblesse d'État } \\
\text { (1989) e em artigos publicados posteriormente por } \\
\text { Bourdieu. }\end{array}$ \\
\hline $\begin{array}{l}\text { Violência } \\
\text { simbólica }\end{array}$ & $\begin{array}{l}\text { Conceito não é utilizado na obra, } \\
\text { embora esteja largamente implícito } \\
\text { no texto. A obra oferece substrato } \\
\text { empírico ao conceito. }\end{array}$ & $\begin{array}{l}\text { Conceito será desenvolvido e refinado nos } \\
\text { trabalhos posteriores de Bourdieu, associado a } \\
\text { discussões sobre poder, dominação e legitimação. }\end{array}$ \\
\hline Illusio & $\begin{array}{l}\text { Conceito não é utilizado na obra, } \\
\text { embora as formulações acerca do que }\end{array}$ & $\begin{array}{l}\text { O conceito de illusio, enquanto ilusão de realidade } \\
\text { compartilhada em um campo, irá encontrar seu }\end{array}$ \\
\hline
\end{tabular}




\begin{tabular}{|c|c|c|}
\hline & $\begin{array}{l}\text { Bourdieu definiu posteriormente } \\
\text { como illusio estão bem desenvolvidas. }\end{array}$ & $\begin{array}{l}\text { grau mais elevado de sistematização em As regras } \\
\text { da arte (1992). }\end{array}$ \\
\hline $\begin{array}{l}\text { Homo } \\
\text { academicus }\end{array}$ & $\begin{array}{c}\text { Conceito não é utilizado na obra, } \\
\text { embora algumas formulações } \\
\text { incipientes estejam presentes, } \\
\text { especialmente no tocante à "magia" } \\
\text { da prática acadêmica e ao carisma } \\
\text { professoral. }\end{array}$ & $\begin{array}{l}\text { Em 1984, Bourdieu publica Homo Academicus, } \\
\text { que analisa em detalhes a lógica e a estrutura do } \\
\text { campo acadêmico francês. }\end{array}$ \\
\hline $\begin{array}{l}\text { Pedagogia } \\
\text { racional }\end{array}$ & $\begin{array}{c}\text { A proposta de uma pedagogia } \\
\text { racional é defendida e apresentada } \\
\text { de modo relativamente bem } \\
\text { desenvolvido. }\end{array}$ & $\begin{array}{c}\text { Tal proposta é abandonada na sociologia madura } \\
\text { de Bourdieu, embora o autor mobilize alguns } \\
\text { preceitos da "pedagogia racional" em suas } \\
\text { formulações sobre a transmissão das técnicas de } \\
\text { trabalho intelectual ao sociólogo, especialmente em } \\
\text { O ofício de sociólogo (publicado pouco tempo após } \\
\text { Os herdeiros, em 1968). }\end{array}$ \\
\hline Ideologia & $\begin{array}{l}\text { Conceito mostra-se recorrente em Os } \\
\text { herdeiros. Os autores falam de uma } \\
\text { "ideologia do dom". }\end{array}$ & $\begin{array}{c}\text { Conceito será criticado e completamente } \\
\text { abandonado na sociologia madura de Bourdieu, } \\
\text { sendo substituído por noções como poder } \\
\text { simbólico, violência simbólica e doxa. }\end{array}$ \\
\hline
\end{tabular}

\section{Referências}

BOURDIEU, Pierre. A distinção: crítica social do julgamento. São Paulo: Edusp; Porto Alegre: Zouk, 2007.

As regras da arte: gênese e estrutura do campo literário. São Paulo: Companhia das Letras, 1996a.

Esboço de uma teoria da prática. In: ORTIZ, Renato (org.). Sociologia: Pierre Bourdieu. São Paulo: Ática, 1983.

Homo Academicus. 2. ed. Florianópolis: Ed. da UFSC, 2013.

O poder simbólico. 13. ed. Rio de Janeiro: Bertrand Brasil, 2010.

O racismo da inteligência. In: Questões de Sociologia. Lisboa: Fim de Século, 2003. p. 277-281.

O senso prático. Petrópolis: Vozes, 2009.

Os três estados do capital cultural. In: NOGUEIRA, Maria Alice; CATANI, Afrânio (orgs.). Escritos de educação. Petrópolis: Vozes, 1998. p. 71-79.

Para uma sociologia da ciência. Lisboa: Edições 70, 2004.

Razões práticas: sobre a teoria da ação. Campinas: Papirus, 1996b.

BOURDIEU, Pierre; CHAMBOREDON, Jean-Claude; PASSERON, JeanClaude. A profissão de sociólogo: preliminares epistemológicas. Petrópolis: Vozes, 1999.

BOURDIEU, Pierre; EAGLETON, Terry. Doxa and Ideology. New Left Review, n. 191, jan. / fev. 1992, p. 111-121. 
Uma análise do desenvolvimento conceitual da sociologia de Pierre Bourdieu a partir da obra "os herdeiros" | Lucas Voigt

BOURDIEU, Pierre; PASSERON, Jean-Claude. A reprodução: elementos para uma teoria do ensino. 5. ed. Petrópolis: Vozes, 2011.

2014.

Os herdeiros: os estudantes e a cultura. Florianópolis: Ed. da UFSC,

GRIGNON, Claude; PASSERON, Jean-Claude. Lo culto y lo popular: miserabilismo y populismo en sociología y literatura. Buenos Aires: Nueva Visión, 1991.

LÉVI-STRAUSS, Claude. Como Surge um Etnógrafo. In: __. Tristes Trópicos. São Paulo: Anhembi, 1957. p. 48-58.

MARX, Karl. As lutas de classes na França de 1848 a 1850. São Paulo: Boitempo, 2012.

MARX, Karl; ENGELS, Friedrich. Manifesto Comunista. São Paulo: Boitempo, 1998.

NOGUEIRA, Cláudio M. Martins; NOGUEIRA, Maria Alice. A sociologia da educação de Pierre Bourdieu: limites e contribuições. Educação \& Sociedade, Campinas, v. 23, n. 78, abr. 2002, p. 15-36.

NOGUEIRA, Maria Alice; NOGUEIRA, Cláudio M. Martins. Bourdieu e a educação. Belo Horizonte: Autêntica, 2004.

VALLE, Ioni Ribeiro. Ler Homo academicus. In: BOURDIEU, Pierre. Homo academicus. 2. ed. Florianópolis: Ed. da UFSC, 2013a. p. 13-20.

O lugar da educação (escolar) na sociologia de Pierre Bourdieu. Revista Diálogo Educacional, Curitiba, v. 13, n. 38, jan. / abr. 2013b, p. 411-437.

Por que ler Os herdeiros meio século depois? In: BOURDIEU, Pierre; PASSERON, Jean-Claude. Os herdeiros: os estudantes e a cultura. Florianópolis: Ed. da UFSC, 2014. p. 9-12.

WEBER, Max. A "objetividade" do conhecimento nas ciências sociais. In: COHN, Gabriel (org.). Max Weber: Sociologia. 7. ed. São Paulo: Ática, 2003. p. $79-127$.

Rejeições religiosas do mundo e suas direções. In: Ensaios de Sociologia. Rio de Janeiro: LTC, 1982. 